\title{
Ecological Studies on Some Insect Pests Infesting Rosemary Plants and Their Associated Predators at Abo-Kabir District Sharkia Governorate Heba A. Ismail ${ }^{1}$; Gamila Sh. Selem ${ }^{2}$ and Ola I. M. Hegab ${ }^{2}$ \\ ${ }^{1}$ Plant Protection Res. Inst. Agric. Res. Center, Dokki, Giza, Egypt. ${ }^{2}$ Plant Protection Dept., Fac. Of Agric., Zagazig Univ., Egypt.
}

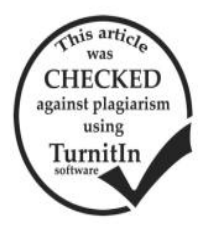

\begin{abstract}
The present studies were carried out to survey and evaluate the population densities of some insect pests infesting rosemary plants and their associated predators during the two successive seasons of 2013 and 2014 at Abo-Kabir district, Sharkia Governorate. The obtained results are summarized as follow : Seven insect species belonging to seven families and four orders were recorded as insect pests on rosemary plants. Bemisia tabaci (Genn.), Aphis gossypii Glover, Empoasca decipiens (Paoli) and Thrips tabaci Lind. were the most dominant species and recorded 53.95, 19.01, 13.08 and $8.14 \%$ of the total insects numbers, respectively.Bemesia tabaci showed four peaks on $1^{\text {st }}$ August , $22^{\text {nd }}$ August, $19^{\text {th }}$ September and $17^{\text {th }}$ October in the first season and on $24^{\text {th }}$ July, $21^{\text {st }}$ August , $2^{\text {nd }}$ October and $20^{\text {th }}$ November in the second one. A.gossypii had two peaks on $1^{\text {st }}$ August and $29^{\text {th }}$ August in the first season and three peaks on $7^{\text {th }}$ August, $4^{\text {th }}$ September and $25^{\text {th }}$ September in the second season .Temperature and relative humidity influenced B.tabaci populations by 4.4337 and $72.9724 \%$ in the first and second seasons , respectively. Temperature and relative humidity affected $A$. gossypii population by 33.91 and $44.68 \%$ during the two successive seasons, respectively .Five predaceous insect species belonging to five families and four orders were surveyed. Paederus alfierii (Koch), Coccinella undecimpunctata L. and Chrysoperla carnea (Steph.) were the most dominant species inhabiting rosemary plants and representing $52.12,24.00$ and $10.35 \%$ of the total number of predators, respectively.
\end{abstract}

Keywords : Rosemary, survey, insect pests , predators.

\section{INTRODUCTION}

Medicinal and aromatic plants occupied an important position in both Egypt and abroad, for their multiple uses. The demand for these plants is increasing continuously in many important fields e.g. medicinal cure, perfume production, soap and cosmetics, refreshing beverages and nutrition such as mint, sweet basil, rosemary, thyme and others. Also, they are used as spices such as, cumin, coriander, fennel fruits and in natural flavor and aroma additives in food industries, that in addition to its using as insecticides (Abou Zaid, 1988 and Rayad, 2002).

These plants are subjected to infesting with several insect pests species which may cause destructive effects and yield losses. Therefore, it is necessary and valuable to study such insect pests that cause economic damage in both quantity and quality of these products to try decreasing their hazards as possible. A number of investigators have surveyed the insects inhabiting different medicinal and aromatic plants (Hammad \& Mohsen 2000, Afsah 2005, Banjo et al., 2006, Abd ElMegid, 2007,Abd El-Moneim et al.,2011 and Bernal et al.,2012).

The present work was conducted to contribute a better knowledge about the following objectives:

1. Survey the insect pests infesting rosemary plants and their associated predators.

2. Seasonal abundance of the main insect pests and their predators in relation with prevailing temperature and relative humidity.

\section{MATERIALS AND METHODS}

\section{Field experiments}

The present investigation was carried out at AboKabir district,Sharkia Governorate, Egypt, during 2013 and 2014 growing seasons to survey the insect pests infesting rosemary (Rosmarinus officilanis L) and their associated predators.

An area of about $500 \mathrm{~m}^{2}$ was prepared and divided into three replicates (each about 150 $\mathrm{m}^{2}$ ). Rosemary seedlings were transplanted on $10^{\text {th }}$ April 2013.

The experimental area was designed according to a complete randomized block design .Normal agricultural practices were applied and no pesticidal treatments were used during the period of investigation. Sampling technique.

Two sampling techniques were used for surveying and counting inhabitant plants, i.e. direct plant sampling and use of insect sweep net method.

\section{Plant samples}

Weekly samples of 20 tillers/replicate were collected randomly from different levels of plant height and continued to the end of the experimental period.All the collected samples were kept in tightly closed paper bags and transferred to the laboratory where they were carefully examined by using a binocular microscope .The stages of each insect species associated with samples were counted and recorded. Unknown immature stages of the predators were reared individually till adult emergence according to Hammad and Mohsen (2000) and Afsah (2005).

Daily records of temperature and relative humidity during the period of the investigation were obtained from the Meteorological station in Abo-Kabir district, Sharkia Governorate. Values of simple correlation (r), partial regression (b) and coefficient of determination (C.D.) were calculated according to Snedecor and Cochran (1987).

Sweep net

An insect sweep net with a diameter of $30 \mathrm{~cm}$ and $70 \mathrm{~cm}$ in depth was used. Sweep was conducted weekly and each sample consisted of 20 double strokes. These samples were taken by walking diagonally across the 
experimental area. Caught insect species were transferred to plastic sacs containing pieces of cotton saturated with ether for anesthetizing the collected insects. The plastic sacs were well tied by rubber bands and taken to the laboratory for counting, identification and recording according to Hassanein et al. (1995) and Abd El-Megid (2007).

\section{RESULTS AND DISCUSSION}

\section{Survey and population densities of insect pests on rosemary plants.}

Seven insect species belonging to seven families and four orders were recorded as indicated in Table (1). The main insect species were Bemisia tabaci (Genn.), Aphis gossypii Glover, Empoasca decipiens (Paoli) and Thrips tabaci Lind. B. tabaci was the most dominant species and comprised $52.59 \%$, followed by $A$. gossypii, E. decipiens and T. tabaci with values of $19.30,13.26$ and $8.45 \%$ of the total number of insect pests, respectively in the first season (2013). The same trends were found in the second season (2014), were the relative densities of $B$. tabaci were $56.85 \%$, while $A$. gossypii, E. decipiens and $T$. tabaci recorded 18.41, $12.70,7.47 \%$, respectively. Moreover direct counting proved to be the most effective method for the estimating of B. tabaci, A. gossypii, while sweep net was effective for collecting $E$. decipiens and T. tabaci. Different species were recorded on rosemary plants by Ismail (2001) who found that Acrolytus insubricus (Scop.), Homorcoryphus nitidulus (Scop.), Galeatus scropticus Saund, Myzus persicae Sulzer, Cosmolyce baeticus L. and Tropinota Squalidae (Scop.) were the most dominant species on rosemary plants. Also, Sharma et al.(2014) recorded Nezara viridula (Linn.), Dysdersus Cingulatus (Fabr.), Helicoverpa armigera and Drosich mangiferae (Green) as the main pests on rosemary plants in India, and Negasu et al. (2016) reported that cottony cushion scale Icerya purchasi Mackell was the major pest on rosemary plants with $25 \%$ infestation rate and they added that I. purchasi was widely distributed in most of the survey areas in Ethiopia.

Table 1.Total numbers of insect pests recorded on rosemary plants at Abo-Kabir district, Sharkia Governorate during 2013 and 2014 growing seasons.

\begin{tabular}{|c|c|c|c|c|c|c|c|c|c|c|}
\hline \multirow[b]{2}{*}{ Insect species } & \multicolumn{4}{|c|}{2013} & \multicolumn{4}{|c|}{2014} & \multicolumn{2}{|c|}{ General } \\
\hline & P.S. & S.N. & $\begin{array}{c}\text { Total } \\
\text { number }\end{array}$ & $\%$ & P.S. & S.N. & $\begin{array}{c}\text { Total } \\
\text { number }\end{array}$ & $\%$ & $\begin{array}{c}\text { Total } \\
\text { numbe } \\
\mathbf{r}\end{array}$ & $\%$ \\
\hline Bemisia tabaci (Genn.) (Homoptera: Aelyrodidae ) & 4298 & 1226 & 5524 & 52.59 & 2086 & 690 & 2776 & 56.85 & 8300 & 53.95 \\
\hline Aphis gossypii Glover(Homoptera:Aphididae ) & 1483 & 543 & 2026 & 19.30 & 510 & 389 & 899 & 18.41 & 2925 & 19.01 \\
\hline Empoasca decipiens (Paoli)(Homoptera: Cicadellidae ) & 146 & 1247 & 1393 & 13.26 & 72 & 548 & 620 & 12.70 & 2013 & 13.08 \\
\hline Thrips tabaci Lind.(Thysanoptera:Thripidae ) & 281 & 607 & 888 & 8.45 & 80 & 285 & 365 & 7.47 & 1253 & 8.14 \\
\hline Nezara viridula L.(Hemiptera:Pentatomidae ) & 11 & 471 & 482 & 4.59 & 0 & 147 & 147 & 3.01 & 629 & 4.09 \\
\hline Spodoptera littoralis (Boisd) (Lepidoptera: Noctuidae ) & 35 & 91 & 126 & 1.20 & 11 & 37 & 48 & 1.00 & 174 & 1.13 \\
\hline Vanessa cardui (Linn.) (Lepidoptera :Nymphalidae ) & 0 & 64 & 64 & 0.61 & 0 & 28 & 28 & 0.57 & 92 & 0.60 \\
\hline General Total & 6254 & 4249 & 10503 & 100 & 2759 & 2124 & 4883 & 100 & 15386 & 100 \\
\hline
\end{tabular}

2. Population density of the main insect pests on rosemary plants and their relationships with some climatic factors.

\section{Bemisia tabaci (Genn.)}

Data presented in Table (2) indicated that the initial infestation with $B$. tabaci took place on $20^{\text {th }}$ June by three individuals/sample. The infestation increased gradually and reached its maximum on $1^{\text {st }}$ August, $22^{\text {nd }}$ August, $19^{\text {th }}$ September and $17^{\text {th }}$ October by 273,464 , 192 and 374 individuals/sample at mean temperature of 29.86, 28.43, 28.57 and $22.57^{\circ} \mathrm{C}$ and 53.29, 54.00, 51.00 and $52.14 \%$ R.H., in the first season. In the second season B. tabaci started to appear on rosemary plants on $26^{\text {th }}$ June with four individuals/samples. The peaks were occurred on $24^{\text {th }}$ July, $21^{\text {st }}$ August, $2^{\text {nd }}$ October and $20^{\text {th }}$ November with numbers of 160,97 , 91 and 218 individuals/samples at means of 28.71 , 29.43, 25.14 and $19.43^{\circ} \mathrm{C}$ and 55.00, 54.86, 53.71 and $63.43 \%$ R.H., consecutively. The mean number of $B$. tabaci in the first season (165.31 individuals/samples) was relatively higher as compared with that in the second one (80.23 individuals/samples). In general, the B. tabaci population was higher in the first season than that in the second one. Such findings are agreed with the results of Ahmad (1990) and Hassanien et al. (1995), as they found that the highest population abundance of $B$. tabaci was recorded during August and September.

Statistical analysis of data compiled in Table (3) indicated that there were negative insignificant and significant correlations between the weekly number of B.tabaci and means of temperature in both seasons, whereas (r) values were -0.2672 and $-0.8185^{*}$ in the first and the second seasons, respectively .Relative humidity showed positive insignificant and significant effects, with $(\mathrm{r})$ values of 0.2566 and $0.6113^{*}$ in the two seasons respectively. Temperature and relative humidity influenced the whitefly population by $4.4337 \%$ in the first season and $72.9724 \%$ in the second one.

\section{Aphis gossypii Glover}

As shown in Table (4) it is cleared that rosemary plants were free from infestation with cotton aphid in the first month of inspection in both growing seasons .In the first season the initial incidence of $A$. gossypii occurred on 4th July with 13 individuals/samples. Afterwards, the insect population density fluctuated to show that two peaks of abundance. The first peak was on 1st August with 125 individuals/sample at means of $29.86{ }^{\circ} \mathrm{C}$ and $53.29 \%$ R.H. The second peak took place 
on $29^{\text {th }}$ August with 122 individuals/sample at $29.67{ }^{\circ} \mathrm{C}$ and $56.67 \%$ R.H. In the second season the first appearance of the insect was on $3^{\text {rd }}$ July with three individuals/sample. A. gossypii had three peaks on 7 th August, 4th September and 25th September with 53, 42 and 31 individuals/sample at mean temperature of 29.71, 29.57 and $27.89^{\circ} \mathrm{C}$ and 50.14, 49.71 and $47.22 \%$, respectively. The mean numbers of the cotton aphid were 57.04 and 19.62 individuals/samples during the two growing seasons, respectively .These results took the same trend with those of Abou- Elhagag (1983), Ahmad (1990) and Al-Shannaf (1994) who found that $A$. gossypii appeared on roselle plants from mid-June to early December with one to four peaks of activity. They added that the highest population density of A. gossypii occurred in August, September and October.

The results tabulated in Table (5) obviously demonstrated that there were positive significant correlation between $A$. gossypii population and mean temperature in both seasons, whereas (r) values were $0.4458^{*}$ and $0.5506^{*}$, respectively. Relative humidity showed positive insignificant effects, with $(r)$ values of 0.1708 in the first season and 0.0267 in the second one. Temperature and relative humidity affected $A$. gossypii population by 33.91 and $44.68 \%$ in 2013 and 2014 growing seasons, respectively.

Table 2. Population density of Bemisia tabaci (Genn.) on rosemary plants by plant sample method during 2013 and 2014 growing seasons.

\begin{tabular}{|c|c|c|c|c|c|c|c|}
\hline \multirow{3}{*}{$\begin{array}{l}\text { Sampling } \\
\text { Date }\end{array}$} & \multirow{3}{*}{$\begin{array}{l}\text { No. of insects / } \\
\text { sample }\end{array}$} & \multirow{2}{*}{\multicolumn{2}{|c|}{$\begin{array}{l}2013 \\
\text { Corresponding means } \\
\text { of }\end{array}$}} & \multirow{3}{*}{$\begin{array}{l}\text { Sampling } \\
\text { Date }\end{array}$} & \multirow{3}{*}{$\begin{array}{l}\text { No. of insects } \\
\quad \text { / sample }\end{array}$} & \multicolumn{2}{|l|}{2014} \\
\hline & & & & & & \multicolumn{2}{|c|}{ Corresponding means of } \\
\hline & & Temp. ${ }^{\circ} \mathrm{C}$ & R.H.\% & & & Temp. ${ }^{\circ} \mathrm{C}$ & R.H.\% \\
\hline Jun.,6,2013 & 00 & 28.71 & 39.43 & Jun.,5.2014 & 00 & 26.71 & 39.57 \\
\hline 13 & 00 & 27.57 & 45.14 & 12 & 00 & 26.71 & 51.71 \\
\hline 20 & 03 & 27.71 & 49.43 & 19 & 00 & 29.14 & 40.86 \\
\hline 27 & 09 & 28.67 & 48.78 & 26 & 04 & 27.11 & 47.44 \\
\hline Jul.,4 & 24 & 27.14 & 58.57 & Jul.,3 & 37 & 28.70 & 54.86 \\
\hline 11 & 53 & 27.71 & 60.57 & 10 & 88 & 29.86 & 51.00 \\
\hline 18 & 226 & 27.86 & 57.86 & 17 & 132 & 27.57 & 55.29 \\
\hline 25 & 270 & 28.40 & 51.50 & 24 & 160 & 28.71 & 55.00 \\
\hline Aug.,1 & 273 & 29.86 & 53.29 & 31 & 158 & 30.00 & 49.67 \\
\hline 8 & 230 & 28.71 & 54.14 & Aug.,7 & 52 & 29.71 & 50.14 \\
\hline 15 & 263 & 29.29 & 59.29 & 14 & 45 & 29.00 & 56.43 \\
\hline 22 & 464 & 28.43 & 54.00 & 21 & 97 & 29.43 & 54.86 \\
\hline 29 & 138 & 29.67 & 56.67 & 28 & 55 & 30.20 & 56.80 \\
\hline Sep.,5 & 142 & 28.00 & 59.71 & Sep.,4 & 60 & 29.57 & 49.71 \\
\hline 12 & 176 & 27.71 & 53.43 & 11 & 74 & 28.14 & 54.00 \\
\hline 19 & 192 & 28.57 & 51.00 & 18 & 81 & 28.43 & 50.42 \\
\hline 26 & 181 & 24.78 & 55.22 & 25 & 85 & 27.89 & 47.22 \\
\hline Oct.,3 & 150 & 23.57 & 50.29 & Oct.,2 & 91 & 25.14 & 53.71 \\
\hline 10 & 172 & 23.29 & 58.43 & 9 & 48 & 23.71 & 57.86 \\
\hline 17 & 374 & 22.57 & 52.14 & 16 & 61 & 23.43 & 56.20 \\
\hline 24 & 339 & 21.29 & 62.29 & 23 & 65 & 24.29 & 43.14 \\
\hline 31 & 216 & 21.67 & 72.00 & 30 & 68 & 21.00 & 59.33 \\
\hline Nov.,7 & 175 & 22.29 & 65.43 & Nov.,6 & 95 & 21.00 & 51.00 \\
\hline 14 & 127 & 21.29 & 70.71 & 13 & 136 & 21.14 & 56.86 \\
\hline 21 & 60 & 19.57 & 63.43 & 20 & 218 & 19.43 & 63.43 \\
\hline 28 & 41 & 21.67 & 43.56 & 27 & 176 & 17.67 & 63.78 \\
\hline Total & 4298 & & & Total & 2086 & & \\
\hline Mean & 165.31 & & & Mean & 80.23 & & \\
\hline
\end{tabular}

Table 3. Effect of weekly means of temperature and relative humidity on the population density of Bemisia tabaci (Genn.) on rosemary plants during 2013 and 2014 growing seasons.

\begin{tabular}{lcccccc}
\hline \multirow{2}{*}{ Climatic factors } & \multicolumn{2}{c}{ Simple correlation (r) } & \multicolumn{2}{c}{ Partial regression (b) } & \multicolumn{3}{c}{$\begin{array}{c}\text { Coefficient of } \\
\text { determination }\end{array}$} \\
& $\mathbf{2 0 1 3}$ & $\mathbf{2 0 1 4}$ & $\mathbf{2 0 1 3}$ & $\mathbf{2 0 1 4}$ & $\mathbf{2 0 1 3}$ & $\mathbf{2 0 1 4}$ \\
\hline Mean Temp. & -0.2672 & $-0.8185^{*}$ & -3.0585 & -13.4691 & 0.6383 & 22.2868 \\
Mean R.H.\% & 0.2566 & $0.6113^{*}$ & 1.4603 & 9.2700 & 0.8151 & 27.8156 \\
Interaction Tempx R.H. & & & & & 2.9803 & 22.8700 \\
Total C.D. & & & & & 4.4337 & 72.9724 \\
$*$ P $>\mathbf{0 . 0 5}$ significant & & & & & &
\end{tabular}


Table 4. Population denisty of Aphis gossypii Glover on rosemary plants by plant sample method during 2013 and 2014 growing seasons.

\begin{tabular}{|c|c|c|c|c|c|c|c|}
\hline \multirow{3}{*}{$\begin{array}{l}\text { Sampling } \\
\text { Date }\end{array}$} & \multirow{3}{*}{$\begin{array}{c}\text { No. of insects / } \\
\text { sample }\end{array}$} & \multicolumn{2}{|c|}{2013} & \multirow{3}{*}{$\begin{array}{l}\text { Sampling } \\
\text { Date }\end{array}$} & \multirow{3}{*}{$\begin{array}{l}\text { No. of insects } \\
\quad \text { / sample }\end{array}$} & \multicolumn{2}{|l|}{2014} \\
\hline & & \multicolumn{2}{|c|}{$\begin{array}{c}\text { Corresponding means } \\
\text { of }\end{array}$} & & & Correspon & means of \\
\hline & & Temp. ${ }^{\circ} \mathrm{C}$ & R.H.\% & & & Temp. ${ }^{\circ} \mathrm{C}$ & R.H.\% \\
\hline Jun.,6,2013 & 00 & 28.71 & 39.43 & Jun.,5.2014 & 00 & 26.71 & 39.57 \\
\hline 13 & 00 & 27.57 & 45.14 & 12 & 00 & 26.71 & 51.71 \\
\hline 20 & 00 & 27.71 & 49.43 & 19 & 00 & 29.14 & 40.86 \\
\hline 27 & 00 & 28.67 & 48.78 & 26 & 00 & 27.11 & 47.44 \\
\hline Jul.,4 & 13 & 27.14 & 58.57 & Jul.,3 & 3 & 28.70 & 54.86 \\
\hline 11 & 71 & 27.71 & 60.57 & 10 & 6 & 29.86 & 51.00 \\
\hline 18 & 90 & 27.86 & 57.86 & 17 & 10 & 27.57 & 55.29 \\
\hline 25 & 108 & 28.40 & 51.50 & 24 & 26 & 28.71 & 55.00 \\
\hline Aug., 1 & 125 & 29.86 & 53.29 & 31 & 49 & 30.00 & 49.67 \\
\hline 8 & 104 & 28.71 & 54.14 & Aug.,7 & 53 & 29.71 & 50.14 \\
\hline 15 & 110 & 29.29 & 59.29 & 14 & 47 & 29.00 & 56.43 \\
\hline 22 & 112 & 28.43 & 54.00 & 21 & 45 & 29.43 & 54.86 \\
\hline 29 & 122 & 29.67 & 56.67 & 28 & 40 & 30.20 & 56.80 \\
\hline Sep.,5 & 75 & 28.00 & 59.71 & Sep.,4 & 42 & 29.57 & 49.71 \\
\hline 12 & 69 & 27.71 & 53.43 & 11 & 27 & 28.14 & 54.00 \\
\hline 19 & 66 & 28.57 & 51.00 & 18 & 27 & 28.43 & 50.42 \\
\hline 26 & 62 & 24.78 & 55.22 & 25 & 31 & 27.89 & 47.22 \\
\hline Oct.,3 & 60 & 23.57 & 50.29 & Oct.,2 & 28 & 25.14 & 53.71 \\
\hline 10 & 58 & 23.29 & 58.43 & 9 & 26 & 23.71 & 57.86 \\
\hline 17 & 46 & 22.57 & 52.14 & 16 & 17 & 23.43 & 56.29 \\
\hline 24 & 40 & 21.29 & 62.29 & 23 & 14 & 24.29 & 43.14 \\
\hline 31 & 38 & 21.67 & 72.00 & 30 & 9 & 21.00 & 59.33 \\
\hline Nov.,7 & 35 & 22.29 & 65.43 & Nov.,6 & 7 & 21.00 & 51.00 \\
\hline 14 & 33 & 21.29 & 70.71 & 13 & 1 & 21.14 & 56.86 \\
\hline 21 & 28 & 19.57 & 63.43 & 20 & 2 & 19.43 & 63.43 \\
\hline 28 & 18 & 21.67 & 43.56 & 27 & 00 & 17.67 & 63.78 \\
\hline Total & 1483 & & & Total & 510 & & \\
\hline Mean & 57.04 & & & Mean & 19.62 & & \\
\hline
\end{tabular}

Table 5. Effect of weekly means of temperature and relative humidity on the population density of Aphis gossypii Glover on rosemary plants during 2013 and 2014 growing seasons.

\begin{tabular}{lcccccc}
\hline \multirow{2}{*}{ Climatic factors } & \multicolumn{2}{c}{ Simple correlation (r) } & \multicolumn{2}{c}{ Partial regression (b) } & \multicolumn{3}{c}{$\begin{array}{c}\text { Coefficient of } \\
\text { determination }\end{array}$} \\
& $\mathbf{2 0 1 3}$ & $\mathbf{2 0 1 4}$ & $\mathbf{2 0 1 3}$ & $\mathbf{2 0 1 4}$ & $\mathbf{2 0 1 3}$ & $\mathbf{2 0 1 4}$ \\
\hline Mean Temp. & $0.4458^{*}$ & $0.5506^{*}$ & -2.9675 & 2.1783 & 3.9928 & 28.5954 \\
Mean R.H.\% & 0.1708 & 0.0267 & -1.7122 & -0.5637 & 7.4466 & 5.0469 \\
Interaction Tempx R.H. & & & & & 22.4704 & 11.0348 \\
Total C.D. & & & & & 33.91 & 44.68 \\
$* \mathbf{P}>\mathbf{0 . 0 5}$ significant & & & & & &
\end{tabular}

3.Survey and population densities of predatory insects.

Results summarized in Table (6) indicated that five predaceous species belonging to five families and four orders were recorded. The orders have been arranged descendingly according to their general relative densities as follows :Coleoptera (76.12\%), Neuroptera (10.35\%), Diptera $(8.82 \%)$ and Hymenoptera (4.71\%). Coleopterous species were Paederus alfierii (Koch) and Coccinella undecimpunctata L. while Neuroptera, Diptera and Hymenoptera were represented only by one species, viz. Chrysoperla carnea (Steph.), Metasyrphus corollae (Fabr.) and Polistes gallicae L., respectively.
$P$. alfierii was the most dominant species, accounting $52.12 \%$ of the whole recorded predators. It was followed by $C$. undecimpunctata , C. carnea, M.corollae and P. gallicae, with values of 24.00, $10.35,8.82$ and $4.71 \%$, respectively. Moreover, sweep net technique proved to be the effective method for collecting adults of the all previously mentioned predators. These results are in agreement with those Ismail (2001) who reported that $C$.carnea and $P$. gallicae were the most important predaceous species on rosemary plants infested with insect pests. 
Table 6. Survey and population densities of insect predators on rosemary plants at Abo-Kabir district, Sharkia Governorate during 2013 and 2014 growing seasons.

\begin{tabular}{|c|c|c|c|c|c|c|c|c|c|c|c|c|}
\hline \multirow[b]{2}{*}{$\begin{array}{l}\text { Order } \\
\text { Family }\end{array}$} & \multirow[b]{2}{*}{ Species } & \multirow{2}{*}{$\begin{array}{l}\text { Recorde } \\
\text { d Stage }\end{array}$} & \multicolumn{4}{|c|}{2013} & \multicolumn{4}{|c|}{2014} & \multicolumn{2}{|c|}{ General } \\
\hline & & & P.S. & S.N, & $\begin{array}{c}\text { Total } \\
\text { number }\end{array}$ & $\%$ & P.S. & S.N, & $\begin{array}{c}\text { Total } \\
\text { number }\end{array}$ & $\%$ & $\begin{array}{c}\text { Total } \\
\text { number }\end{array}$ & $\%$ \\
\hline $\begin{array}{l}\text { Coleoptera } \\
\text { Staphylinidae }\end{array}$ & $\begin{array}{c}\text { Paederus alfierii } \\
\text { (Koch.) }\end{array}$ & A & 50 & 265 & 315 & 54.78 & 17 & 111 & 128 & 46.55 & 443 & 52.12 \\
\hline Coccinellidae & $\begin{array}{c}\text { Coccinella } \\
\text { undecimpunctata } \mathrm{L} \text {. }\end{array}$ & L\&P\&A & 21 & 115 & 136 & 23.65 & 9 & 59 & 68 & 24.73 & 204 & 24.00 \\
\hline $\begin{array}{l}\text { Total } \\
\%\end{array}$ & & & & & & & & & & & 647 & 76.12 \\
\hline $\begin{array}{l}\text { Neuroptera } \\
\text { Chrysopidae }\end{array}$ & $\begin{array}{c}\text { Chrysoperla carnea } \\
\text { (Steph.) }\end{array}$ & E\&L\&A & 12 & 40 & 52 & 9.04 & 5 & 31 & 36 & 13.09 & 88 & 10.35 \\
\hline $\begin{array}{l}\text { Total } \\
\%\end{array}$ & & & & & & & & & & & 88 & 10.35 \\
\hline $\begin{array}{l}\text { Diptera } \\
\text { Syrphidae }\end{array}$ & $\begin{array}{c}\text { Metasyrphus corollae } \\
\text { (Fabr.) }\end{array}$ & L\&P\&A & 00 & 48 & 48 & 8.35 & 00 & 27 & 27 & 9.82 & 75 & 8.82 \\
\hline $\begin{array}{l}\text { Total } \\
\%\end{array}$ & & & & & & & & & & & 75 & 8.82 \\
\hline $\begin{array}{l}\text { Hymenoptera } \\
\text { Vespidae }\end{array}$ & Polistes gallicae L. & A & 00 & 24 & 24 & 4.18 & 00 & 16 & 16 & 5.81 & 40 & 4.71 \\
\hline $\begin{array}{l}\text { Total } \\
\%\end{array}$ & & & & & & & & & & & 40 & 4.71 \\
\hline General Total & & & 83 & 492 & 575 & 100.00 & 31 & 244 & 275 & 100.00 & 850 & 100.00 \\
\hline
\end{tabular}

\section{REFERENCES}

Abd El-Megid, J.E., 2007.Main insect pests of mint and their associated natural enemies at Hehia district, Sharkia Governorate. Zagazig J. Agric.Res., 34 (3) : $513-540$.

Abd El-Moneim, A.S.M.; T.E.Abd El-Wahab and N.A.Farag, 2011. Prevailing insects roselle plant, Hibiscus sabdariffa L. and their efficiency on pollinations. Archives of phytopathology and plant protection, 44 (3): $242-252$.

Abou-El-hagag, G.S. ,1983.Field and laboratory studies on certain pests of medicinal and aromatic plants. M.Sc. Thesis, Fac. Of Agric., Assuit Univ.

Abou-Zaid, E.N. ,1988.Aromatic and medicinal plants their agricultural and medicinal products, El-Dar El-Arabia for publishing, Cairo.

Afsah, A.F.E. ,2005.Studies on some pests attacking medicinal and aromatic plants. Ph.D.Thesis, Fac. Of Agric, Zagazig Univ.

Ahmad, A.M.T. ,1990.Studies on some insect pests infesting certain medicinal plants. Ph.D.Thesis, AlAzhar Univ : 148 pp.

Al-Shannaf, H.M.A. ,1994.Ecological studies on certain cotton pests in Sharkia Governorate .M.Sc. Thesis, Zagazig Univ : 188 pp.

Banjo A.D.; O.A. Lawal and S.A. Aina ,2006.Insect diversity of two medicinal labiatatae in southwestern Nigeria. Journal of Entomology. 3(4) : $248-304$.
Bernal A.B.; R.C. Deroncele and T.P.Diaz ,2012.Pests and diseases that affect whitebasil Ocimum basilicum growing under protected condition. Fitosanidad. 16(2): 87-89.

Hammad, K.A.A. and A.M.Mohsen ,2000.Insect infesting roselle and their associated natural enemies in newly reclaimed sandy land. Egypt. J.Appl. Sci., 15 (7): $618-642$.

Hassanein, S.S.M; E.M.Metwally and A.F.E Afsah ,1995.Daily flight activity of certain sap sucking insects invading some vegetable crops and efficiency of two methods for trapping them at Gemmeza region, Egypt.Egypt. J.Agric.Res., 7(30): 639-651.

Ismail, O.M.N. ,2001.Studies on some insects attacking aromatic and medicinal plants M.Sc. Thesis, Fac.of Agric., Cairo Univ.

Negasu, G.; N.Banchiamlak and M.Mihirat ,2016.Composition, distribution and economic importance of insect pests oprioritized aromatic plants in some growing of Ethiopia. Biological and Biomedical Research 4 (1): 1-9.

Rayad, L. ,2002.Producing and manufacturing aromatic and medicinal plants in Egypt, National planning Institute Diploma.

Sharma, P.C.; A.Kumar; P.K. Mehta and R.Singh ,2014. Survey studies on insect pests associates with important medicinal plants in Himachal Pradesh. Indian J. Sci. Res. and Tech. 2(4): 2-7.

Snedecor, G.W. and W.G. Cochran ,1987.Statistical methods. $8^{\text {th }}$ Ed. The Iowa State Univ. press. Ames, Iowa, U.S.A. 
دراسات إيكولوجية على بعض الآفات الحشرية التى تصيب نباتات الروزمارى والمفترسات المرتبطة بها في منطقة

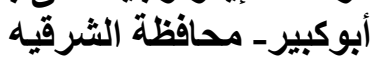

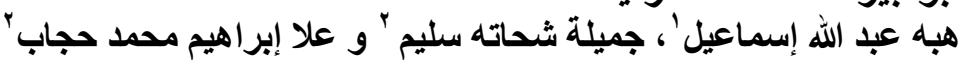

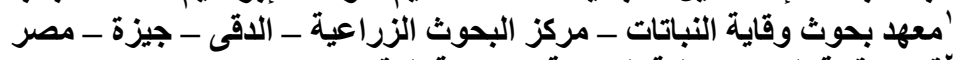

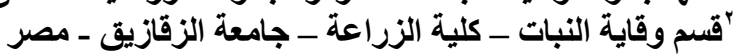

أجريت دراسات لحصر أهم الآفات الحشرية التي تصيب نباتات الروزماري و المفترسات الحشرية المصاحبه لها بمنطقة

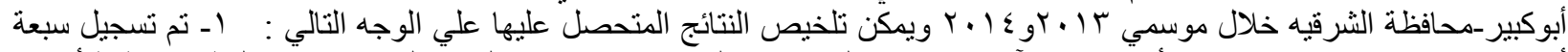

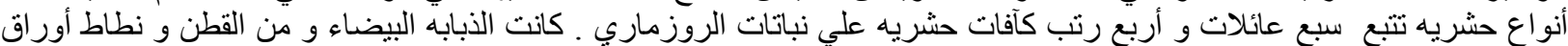

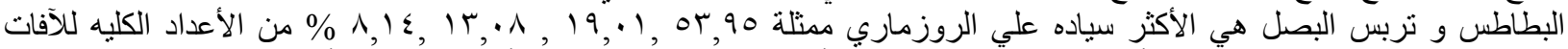

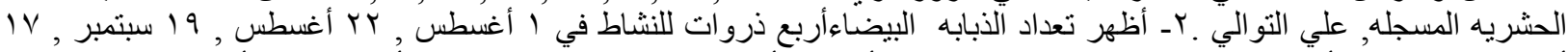

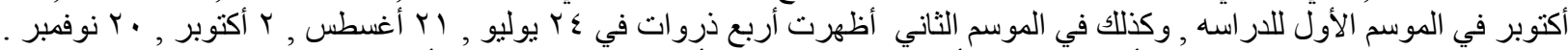

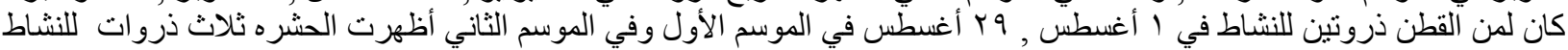

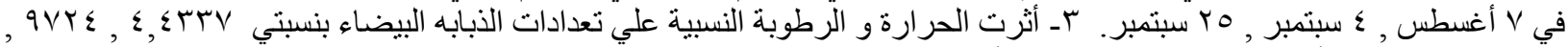

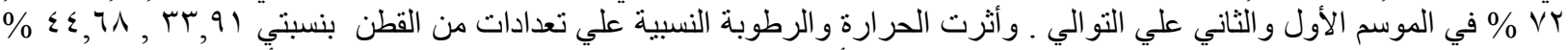

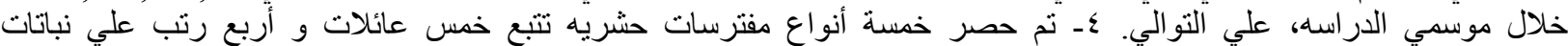

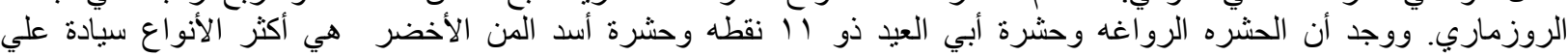

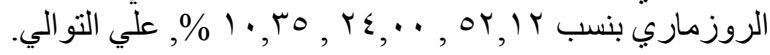

